\title{
LEADING LIKE A FOOL: AN EVALUATION OF PAUL'S FOOLISHNESS IN 2 CORINTHIANS 11:16-12:13
}

\author{
JEFFREY M. HORNER*
}

Southern Baptist Theological Seminary

\begin{abstract}
The apostle Paul employed many techniques that demonstrated his leadership. One of the most understated instances of that is in his 'Fool's Speech' in 2 Corinthians 11:1612:13. Paul flaunted his rhetorical skills in calling attention to his own shortcomings, in lampooning his opponents, and in revealing the source of his assurance for foolishness. This article evaluates Paul's rhetorical masterpiece calling the Corinthians to humble submission to his apostleship by synthesizing the work of both Jennifer Glancy and Lawrence Welborn with Don Howell. [All Scriptural quotes are taken from the New American Standard Bible @ 1977]
\end{abstract}

KEYWORDS: 'Fool's Speech', rhetoric, leadership, satire, Paul

\section{Introduction}

Fool. The term carries nearly as much opprobrium today as it did in the Greco-Roman world. Philosophers scorned folly and playwrights used fools for comic relief and satirical purposes. In the New Testament, Paul uses two different words to mean foolishness: $\mu \omega \rho i \alpha$ and $\dot{\alpha} \phi \rho o \sigma u ́ \nu \eta$. 'While the Gospel writers use these terms more or less interchangeably, Paul seems to make a distinction between the associative meaning attached to these two word families' (Farmer 2003: 143). Paul's distinctive usage of these two words appears most clearly when examining both 1 Corinthians and 2 Corinthians. He exclusively uses $\mu \omega \rho i ́ \alpha$ in 1 Corinthians and exclusively uses $\dot{\alpha} \phi \rho o \sigma u ́ \nu \eta$ in 2 Corinthians. The 'While Paul's use of aphron and aphrosyne in 2 Corinthians recalls the OT association between foolishness and sin or disobedience, his use of moraine, moros, and moria in 1 Corinthians 1-4 calls up images of the mimic fool' (Farmer 2003: 143). This distinction emerges more profoundly upon consideration of Paul's usage when chastising the pseudoapostles in 2 Corinthians 11-12. 'In Greek tragedy, $\mu \omega \rho^{\prime} \alpha$ is a kind of 'mad-

* JEFFREY M. HORNER (EdD 2016, Southern Baptist Theological Seminary) is Adjunct Faculty Supervisor at Southern Baptist Theological Seminary. Email: jhorner@sbts.edu. 
ness', a rash and impulsive action that seems to be impelled by a power which confuses human understanding and hides the right path... In the teaching of the philosophers and moralists, $\mu \omega \rho^{i} \alpha$ is a lack of reason or selfunderstanding, the absurdity of an unexamined life. For the rhetorician, it is «sheer folly not to adapt one's style of speaking to the audience and the circumstances of the case' (Welborn 2002: 424). Importantly, Paul's use of $\dot{\alpha} \phi \rho \circ \sigma u v \nu \eta$ when clearly speaking in the manner of a mimic fool highlights the sinfulness of the pseudo-apostle's explicit questioning of Paul's authority and implicit questioning of the gospel he taught. In the early twentieth century, German theologian Hans Windisch coined the term, 'Fool's Speech' to refer to Paul's rhetorical outburst in 2 Corinthians 11:16-12:13 where he emphasizes that he speaks as a fool. 'Windisch thus designated the speech proper in [2 Corinthians 11:21b-12:10], following a lengthy apologetic prologue in [2 Corinthians 11: 1-21a]' (Welborn 1999: 123). Reiterating language he used in 1 Corinthians 1:18-31, Paul 'boasts' of his weaknesses in the Fool's Speech as part of a devastating critique of the pseudo-apostles, who had attacked his apostolic authority. In this article, Paul's apostleship and leadership will be used as near synonyms since the special class of apostles in the New Testament were the first missionaries, church leaders, and writers (or associates of the writers) of the entire canon of the New Testament.

In his doctoral work, Timothy B. Savage contends that, 'There is no explicit evidence in the text of 2 Corinthians to confirm that the opponents were specifically disputing Paul's office as an apostle, nor that they were drawing a link between that office and his authority... Any suggestion that it is specifically Paul's apostleship that is being disputed rests on slim evidence' (Savage 1995: 6). Savage further argues a fine distinction between Paul defending his apostleship and Paul defending his ministry, 'He will not defend himself, either his authority of his apostleship (11:19). Instead it is specifically his «ministry> which he defends (6:3-4), a term better suited to underscoring his humility, not his authority, his service, not his office' (Savage 1995: 7). His distinction seems to be somewhat unnecessary, especially with specific regard to the 'Fool's Speech'. This article argues, in distinction from Timothy B. Savage's assertions, that by setting the speech into its socio-historical literary context, Paul's 'Fool's Speech' emerges from the intersection of his desire both to defend himself as a leader and his desire to juxtapose God's power with his own weakness.

This article will begin by establishing the importance of rhetoric in the Greco-Roman world. It will next discuss Paul's scarred body and its disabling effect on his public speaking due to Greco-Roman assumptions about physical appearance. From there, it proceeds to Paul's strategic adaptation of the personae of comic mimes to further make himself appear foolish in 
his letter to the Corinthians. After establishing Paul's foolishness, this article then turns to Paul's spiritual qualities and his apostolic authority as set forth in this passage. Finally, it unfolds several points about Paul's leadership based on the content and occasion of the 'Fool's Speech' and then concludes.

\section{Paul's Presence: The Importance of Rhetorical Ability}

In the Greco-Roman world, rhetoric stood at the pinnacle of intellectual achievement. John Stott notes that in the first century ad, 'Rhetoric became the primary discipline in Roman higher education... [it] was tremendously popular as a form of public entertainment' (Stott 2002: 55). Specifically taking note of the church at Corinth, he remarks, 'The Corinthians... were still enamored of popular rhetoric. They thought of the gospel as sōphia, and they considered that it should be presented with appropriate ornamentation' (Stott 2002: 44).

Stott's discussion reveals why Paul's inability as a public speaker caused him trouble with the Corinthian church. His lack of facility with spoken Greek contributed to the Corinthians' unimpressed perception of him. Barnett argues, 'Paul concedes that he is «not a trained speaker`... Inadequacy in speech was a long-standing, perceived weakness in Paul, one to which he displayed sensitivity in the First Letter (1 Corinthians 2:1-4). It is likely that the arrival in Corinth after Paul of the rhetorically gifted Apollos (Acts 18:24-28) led the Corinthians to reflect negatively about the apostle's capacities as a public speaker' (Barnett 1997: 508-9). However, despite Paul's unimpressive personal speaking abilities, he marshals great rhetorical skills in written form, as will be demonstrated more completely below in the section entitled: 'Paul the Theatrical Satirist'.

Howell also notes, 'The Corinthians' fascination with human wisdom and oratorical style helps account for the personality-centered factions that developed in the church (1:10-17)' (Howell 2003: 277). Additionally, he writes that Corinth was, 'a culture fascinated by itinerant teachers who espoused Greek wisdom and delivered impressive oratory. Paul refrained from imitating the rhetorical style typical of these sophists' (Howell 2003: 277). Paul's dependence on the Holy Spirit to empower his teaching countered Corinthian cultural norms. Therefore, it was important for Paul to defend-as he did through the skillfully written Fool's Speech-not only his message but also his apostleship since both derived from Christ's commission to Paul to evangelize the Gentiles. Having now examined the importance of rhetoric for Paul in the Greco-Roman world, this article shall now examine how Paul's physical appearance shaped Corinthian perceptions of his message. 


\section{The Importance of Paul's Physical Appearance}

The earliest known accounts of Paul's physical appearance are disfavorable. The Acts of Paul and Thecla states, 'At length they saw a man coming (namely Paul), of a low stature, bald (or shaved) on the head, crooked thighs, handsome legs, hollow-eyed; had a crooked nose; full of grace; for sometimes he appeared as a man, sometimes he had the countenance of an angel' (Fordham University Medieval Sourcebook 2016: 1.7). Unfortunately for Paul, the Greeks and Romans believed that physical appearance indicated much about the general nobility and value of a person. In a significant essay regarding Paul's boasting of beatings in his 'Fool's Speech', Jennifer Glancy writes, 'Every body tells a story; every body tells stories. Each body has multiple stories to tell' (2004: 100). In her article, Glancy clarifies that scars on a man's front convey first century concepts of manliness and courage, whereas scars on a man's back convey servility and cowardice. She notes, 'The ability to order a whipping signaled a person's dominance over another; the inability to resist a whipping, the dishonor of the person whipped... Dishonorable bodies were whippable; honorable bodies were not' (Glancy 2004: 108-9). She also writes that in Paul's Greco-Roman context, '[The fact] that one's body was whipped... constituted evidence of suspect character. Paul's whippability-for his announcement that he had been repeatedly lashed and beaten with rods defined him as eminently beatable-marked him as dishonorable, even contemptible' (Glancy 2004: 111). Here, Glancy highlights the depth of Paul's abasement. Having been beaten by the Jews five times and by the Romans three times, Paul showed himself to be eminently beatable and therefore dishonored. By proclaiming to the Corinthians the extent of the abuse he had received, Paul's acknowledged that his physical appearance marked him as a fool. Glancy reinforces the effect of his appearance on his leadership of the Corinthian church, writing, 'A man who is whipped loses his claim to honor: so what kind of people would acknowledge the authority of leaders who had been publicly whipped?' (Glancy 2004: 117). Additionally, Glancy connects his beaten appearance to Paul's boasting by writing, 'Paul not only specifies the frequency and type of floggings to which he has been subjected: he boasts about those beatings. An emerging consensus holds that Paul's boasting in the [Fool's Speech] exhibits familiarity with protocols of self-praise in rhetorical theory and practice' (Glancy 2004: 118). [For further reading on this stated consensus, see: Spencer AB (1981).] In summary, Glancy provides clear insight into the overall effect of Paul's unimpressive, chastened physical appearance on the Corinthian church, but her work connects Paul's appearance to his response, that of boasting.

In his own study of Paul's leadership qualities, Howell writes, 'Paul was often attacked with ad hominem arguments' (Howell 2003: 266). It is likely 
that for the Corinthians, these critiques of Paul emerged from his perceptions both of his less than beautiful physical appearance and his status as someone who had been repeatedly beaten. Howell clarifies Paul's method of response: 'His opponents sought to undermine his message... by discrediting the messenger. Paul's defenses are not attempts to salve a wounded ego. Rather, Paul's apologetic is driven by a holy zeal to preserve the integrity of the gospel that God has entrusted him with' (Howell 2003: 266). The Corinthian church, who would have fully embraced Greco-Roman assumptions about the connection between lowly status, physical appearance, and whippability, would undoubtedly have believed this to be a persuasive case against both Paul's authority and the gospel he preached. As the apostolic overseer of the Corinthians, Paul needed to defend his authority and did so in an unexpected fashion: by connecting his beaten condition to his claim to leadership for the Corinthian church. Therefore, Glancy lends weight to the assertion that Paul boasted using rhetorical conventions from the classical world. However, he selected an unconventional set of proofs: multiple beatings. Glancy writes, 'Even a single occasion of flogging dishonored a man; multiple occasions of flogging would raise questions about the character of a man unable or unwilling to guard his body against violation, who might even be perceived to invite such treatment' (Glancy 2004: 124). Interestingly Paul, in imitation of Christ, did not seek to defend his physical body against the corporal punishments handed out by the authorities. However, Paul did defend his apostleship through rhetoric against the pseudo-apostles. Glancy records, 'For Paul, the problem is that, in [the Corinthians'] submission to the authority of the super apostles, they have subjugated themselves and the gospel Paul preaches [emphasis added]' (Glancy 2004: 130). It is the subjugation of the gospel that ultimately provokes Paul's devastating, satirical response, to which this article now turns.

\section{Paul the Theatrical Satirist}

By using satirical irony to defend himself, Paul deployed the known conventions of the theater popular in the Greco-Roman world: the mime. Laurence Welborn's article (1999), 'The Runaway Paul', provides an extensive explanation of each of the various voices from well-known mimetic fools. He argues, 'It is impossible that Paul would not have encountered the mimes in the marketplaces of Roman cities, where they performed during the day, and where they slept at night' (Wellborn 1999: 128). Due to the prevalence of these performers, Welborn understands the 'Fool's Speech' through the lens of mimetic convention. He explains the 'fool' (or $\mu \omega \rho o$ s): 'For most Greek readers in the time of Paul... the term $\mu \omega \rho$ ' $\alpha$ designated the attitude and behavior of a particular social type: the lower class buffoon' (Welborn 2002: 424). Paul's adoption of that position in his letter provided 
an accessible reference point for the sophisticated Corinthian church. 'Because the concept of the laughable in the Greco-Roman world was grounded in contemplation of the ugly and defective, those who possessed these characteristics were deemed to be foolish' (Welborn 2002: 424). Welborn also explains mime (and its adjective 'mimetic'): 'As a source of amusement, these lower class types were widely represented on the stage in the vulgar and realistic comedy known as the smime. Through its use in this context, $\mu \omega \rho o ́ \varsigma$ became the 'common generic name for a mimic fool' (Wellborn 2002: 424). This comment appears in starker relief through Paul's usage of the term $\dot{\alpha} \phi \rho o \sigma u ́ \nu \eta$, most commonly used to translate Old Testament concepts of sin, is juxtaposed with his description of himself in mimic language.

Welborn additionally notes, 'A limited cast of characters was associated with the mime... a leading slave, a braggart warrior, an anxious old man, a quack doctor, and so on. The features of the stock characters were established at an early date and remained stable, with local variations, through all periods of the mime and its related forms' (Wellborn 1999: 131). Welborn traces five characters' voices in the Fool's Speech: the leading slave, the braggart warrior, the foolish old man, the learned imposter (2 Corinthians 11:21b-23); (Wellborn 1999: 137), and the runaway slave (2 Corinthians 11:32-33); (Wellborn 1999: 157). His exploration of Paul's use of mimic fools reinforces his assertions that Paul adopts that role in order to satirize the pseudo-apostles' charges against him. 'The combination of several types of fools in the portrait of a single individual is not unique to Paul. Seneca treats Claudis in the same manner in the Apocolocyntosis' (Welborn 1999: 137). Paul's intended audience, 'The church of God which is at Corinth with all the saints who are throughout Achaia' (2 Corinthians 1:1), would have easily identified these stock characters in his Fool's Speech. Welborn comments, 'The several fools in Paul's performance are distinguished from one another by a series of interjections that punctuate the discourse. Although his speech is more concise than some of the mimes... it approximates the length of a recitation by a solo performer' (Wellborn 1999: 137). It is likely that Paul repeatedly notes that he is speaking as a fool (2 Corinthians $11: 17 ; 11: 21 ; 11: 23 ; 12: 1 ; 12: 11)$ in order to guide the reader of his letter and those hearing it that his Fool's Speech is akin to a comic performance. Paul does this much in the same way that modern impersonators give their audiences visual and vocal cues to the idiosyncratic mannerisms of the celebrities they are caricaturing. As Barnett comments, 'It should be noted that 2 Corinthians, like other NT literature and indeed all literature from the period, was written to be read aloud to the audience to whom it was sent' (Barnett 1997: 17). Since Paul's epistles were intended to be read aloud, these comments would have been important to explaining the parodic tone that Paul adopts for this portion of his letter. 
Welborn's connection of Paul's boasting to a mimetic performance strengthens commentary from other New Testament scholars. Murray J. Harris writes, '[Paul] has decided to boast as his opponents do, because he knows the Corinthians' determination to compare him with his rivals and their vulnerability to those who commend themselves. From 11:16-12:13, he engages in ad hominem argumentation, boasting about things that are not 〈boastworthy and answering fools according to their folly (Proverbs 26:5) [Italics original]' (Harris 1976: 389). Paul's decision to boast finds its roots in known conventions of foolish boasting and therefore heightens the tension in Paul's words when he acknowledges the attacks of his opponents and undermines them. In a similar context, Barnett writes: 'It is probable that this ¿Speech〉 mirrors, but so as to parody and also correct, the claims of the newly arrived false apostles... Paul will not attempt to match them in their favorable comparisons of themselves with him. Rather, he will daringly boast of weaknesses, the very weaknesses they deplore, so as to mock his opponents' crassness in boasting while at the same time establish that it is his ministry that authentically replicates the suffering ministry of Christ' (Barnett 1997: 534). It is this connection between Paul's own foolishness and the suffering of Christ that makes Paul's argument bitingly difficult. He uses his identification as a fool to bolster his identification with Christ and to flip the argument around in highlighting God's use of the weak to shame the strong, which brings Him more glory.

Therefore, Paul's repeated assertions that he is 'speaking in foolishness' (2 Corinthians $11: 17 ; 11: 21 ; 11: 23 ; 12: 11$ ) in his 'boasting' (2 Corinthians $11: 16 ; 11: 17 ; 11: 18 ; 11: 30 ; 12: 1 ; 12: 5 ; 12: 6 ; 12: 9)$ characterize the entire speech as a purposeful parody of both his opponents' boasts and the known characteristics of the mime. Welborn asserts, 'In the prologue to the speech in 2 Corinthians 11:1-21a, Paul takes pains to identify the role that he is playing as that of the fool. He repeatedly characterizes his discourse as $\dot{\alpha} \phi \rho \circ \sigma u ́ \nu \eta(11: 1,7)$ and repeatedly refers to himself as an $\dot{\alpha} \phi \rho \omega \nu(11: 16,19)$. These self-references are the linguistic counterpart of the dress and manners by which the fool was identified when he appeared on the mimic stage' (Wellborn 1999: 137-8). Paul parallels the pseudo-apostles' charges against his character with his own 'boasts' in his weakness, comically contrasting their boasting to his truthful relation of his own sufferings on behalf of Christ. To emphasize his truthful 'boasting', Paul inserts an oath in 2 Corinthians 11:31. 'The God and Father of the Lord Jesus, He who is blessed forever, knows that I am not lying'. Barnett comments, 'The latter oath sustains his 'boast' of 'weaknesses' (v. 30; cf. vv. 23-28)' (Barnett 1997: 552).

After establishing his truthfulness, Paul narrates his flight from Damascus. His relation of that story inverts the typical 'first over the wall' imagery common among Roman military conquest boasts. Again, Welborn notes, 
'Paul's account of his descent from the city wall is a parody of the soldier's boast at being the first up the wall in the face of the enemy. The courageous soldier was awarded the corona muralis... awarded by a commander to the man who is first to mount the wall and force his way into an enemy's town' (Wellborn 1999: 119). Instead, Paul is 'first over the wall' in flight from the city: the role of a coward. Murray Harris writes, 'He may be speaking of [the flight] because it was probably the first attempt on his life and such a significant reversal of roles (Acts 9:1,2) that it had been indelibly impressed on his memory' (Harris 1976: 393). Barnett notes, 'Two connected reasons that may best explain these verses and account for their location in relation to the passage following are (1) that being lowered down in these verses symmetrically counterpoises his description of the man who was 〈caught $u p$ > into the third heaven/Paradise $(12: 2,4)$, and (2) that taken together his being lowered down〉 and 〈caught up〉 form a comic-tragic parody of his opponents' boast> of 〈superiority> arising from their <visions and revelations> (12:1)' (Barnett 1997: 553).

Paul's efforts to properly characterize himself as a 'fool' achieve the opposite effect. Only a skilled rhetorician could have so marshalled his argument-using his opponents' criticisms instead to satirize them by acknowledging himself as a 'fool', even using their own words-while displaying a satirical tone that establishes the identity of the true fools. Additionally, Paul's 'boasting' proves ironic because his statements are all true, rather than the exaggerations typically found in mimic comedies. Welborn highlights this by saying:

Throughout the Fool's Speech, however, Paul undermines the aims of the discourse (and the values of his opponents) by ironic treatment of the materials of the genre: his accomplishments are calamities, his revelations unutterable, his healing is inefficacious and his power consists in weakness. These moments of reversal furnish the only real humor in Paul's foolish discourse, startled sighs that occasionally escape at the reversal of the expectations that the genre creates. It is this ironic stance toward his own discourse which confers a polemical power upon Paul's dissimulation (Wellborn 1999: 159-60).

Paul expands the criticisms, boasting about how true they are, and proves himself to be beyond the worst contempt, based on the "wisdom of the world' (1 Corinthians 1:27). By doing so, Paul voids all claims to physical power that he might have. Instead, he focuses his boasting on his knowledge of God and his spiritual commission, proofs to which this article now turns. 


\section{The Spiritual Dimension of Paul's Foolishness}

The more recent arguments of Glancy and Welborn supply helpful modifications of Timothy Savage's argument where he claims: 'Paul's boasting is both deeply ironic and profoundly straightforward' (Savage 2004: 64). Due to the pseudo-apostles openly questioning Paul's authority, he has no choice but to defend his apostolic commission. He does so, not to emphasize his own greatness, but rather to glorify God because He empowers Paul's message. For Paul, his authority as an apostle was inextricably connected to his proclamation of the gospel. He proclaimed the gospel as one commissioned to do so by Christ. He had earlier explained his commission to them in 1 Corinthians when he wrote, 'Last of all, as it were to one untimely born, He appeared to me also. For I am the least of the apostles, who am not fit to be called an apostle, because I persecuted the church of God' (1 Corinthians 15:8-9). Therefore in 2 Corinthians, he vigorously defended his apostleship and, by proxy, the gospel Jesus entrusted to him personally. Thus, his opponents' self-glorification fades beside the Fool's Speech, which instead gives glory to God.

In 2 Corinthians 12:1-6, Paul relates a vision, previously undisclosed to the church at Corinth. Harris notes, 'It should not be overlooked that Paul's mention of his ecstatic rapture was a necessary introduction to what he says about his 'thorn in his flesh' (vv. 7-10), another evidence of his weakness' (Harris 1976: 394). In the same vein, Barnett writes, 'Paul does not deny the substance (that he had such experiences), but their significance! Contrary to the [pseudo-apostles'] hope, such phenomena do not authenticate ministry' (Barnett 1997: 556). Interestingly, Paul relates his receipt of a vision but emphasizes his inability to convey its content. Thus, despite his profound ecstatic experiences, Paul does not consider them any ground for asserting superiority. Barnett notes, 'Despite the grandeur of the experience, it was useless in authenticating his ministry; nothing he heard in Paradise was allowed to be told to others' (Barnett 1997: 562). Rather, his visions have occasioned suffering in his flesh. Therefore, Paul connects these visions to his suffering and abasement. 'Because of the surpassing greatness of the revelations, for this reason, to keep me from exalting myself, there was given me a thorn in the flesh, a messenger of Satan to torment me-to keep me from exalting myself' (2 Corinthians 12:7). Paul did not connect his apostolic authority to these visions. In fact, Barnett writes:

Having urged his apostolicity upon them in the First Letter (1 Corinthians 9:1; 15:8) on the basis of having seen the risen Lord, Paul may not wish to repeat such validation, or enter into 'comparison' with them as if they were on equal terms with him $(10: 12 ; 11: 12)$, as if he needed to reestablish his dominical calling. Rather, it appears that Paul wants that office to be accepted as a given, without further dispute (Barnett 1997: 559). 
For Paul, any successes he had are nothing to boast about, not even his ecstatic visions, since the revelations he received are unutterable. Paul's apostolic authority, then, derives solely from his encounter with the risen Jesus.

\section{Paul's Apostolic Witness}

In 2 Corinthians 12:11-13, Paul reminds the Corinthians that their acceptance of the pseudo-apostles drove him to this scolding. His apostolic authority already had been demonstrated among them. He writes, 'The signs of a true apostle were performed among you with all perseverance, by signs and wonders and miracles'. Thus, Paul seems to believe that he should not have needed to resort to such strong speech, since the Corinthians had already witnessed his authentication of his apostolic ministry-not through relating visions, or powerful, ornamented rhetoric, but according to the empowerment of the Holy Spirit. Paul's authority among them, especially as the founder of the work there, should have never been questioned or doubted in the first place.

For the purposes of understanding Paul's fierce defense of his apostolic authority, it is important to note that Paul had not been the only Christian leader to visit Corinth. Barnett writes:

It was probably not earlier than the summer of $\mathrm{AD} 53$ that Paul at last returned to the Aegean region... In the meantime the Corinthians had received a visit from another Christian leader, the gifted Alexandrian Jew Apollos (Acts 18:2719:1). While there is no hint that Paul's relationship with Apollos was other than cordial, his coming to Corinth must have demonstrated to the Corinthians that Paul's was not the only expression of the gospel and that some, at least, probably regarded it as inferior to Apollos's. Before long Corinth would be graced by a visit from no less a person than Cephas, the leading disciple of the Lord, who had previously assumed the leadership of the Jerusalem church (Barnett 1997: 9-10).

Because of this fact, Paul had already addressed the issue of factions and leadership cults resulting from visits by different the Christian leaders in the first chapter of 1 Corinthians. He had commanded them to agree and emphasized that 'Christ did not send me to baptize, but to preach the gospel, not in cleverness of speech' (1 Corinthians 1:10). Thus, to have to defend his leadership further to the easily swayed Corinthian church surely pained him deeply. Howell writes, 'Paul is somewhat embarrassed by having to make a defense of his character to those who ought to be his strongest defenders (2 Corinthians 10:13-14: 11:1; 12:11)' (Howell 2003: 266-67). Again given the Greco-Roman cultural beliefs about beatings, as presented above, it is likely that Paul's diminutive, beaten body caused the Corinthians to question his leadership and therefore his gospel. Paul claimed apostolic au- 
thority and urged the Corinthians to cast aside their concerns about his appearance and spoken rhetorical deficits. Due to his authority to make apostolic claims, in the 'Fool's Speech' Paul has resoundingly demonstrated the power of God to shame the 'wise' Corinthians through a 'fool', himself. Therefore having established Paul's foolishness, in worldly terms, this article now turns to the connections between Paul's assertions in 1 Corinthians and his embodiment of those assertions in 2 Corinthians.

\section{Continuity of Paul's Thought}

The continuity of both Paul's commands and representations of himself can be found in both of the biblical letters to the Corinthians. The purpose of this article is not to enter into the debate over the source of 2 Corinthians 10-13, but rather to link the Fool's Speech to Paul's specific assertion in 1 Corinthians 1:27-29 regarding foolishness. Paul writes, 'God has chosen the foolish things of the world to shame the wise, and God has chosen the weak things of the world to shame the things which are strong and the base things of the world and the despised God has chosen, the things that are not, so that He may nullify the things that are, so that no man may boast before God' Stott notes, when commenting on 1 Corinthians 1, 'Paul's emphasis is that God's power operates only in the salvation of the weak. Therefore, if the strong hope to be saved, they must acknowledge their weakness'. Thus, Paul's willing exhibition of his own weakness in the Fool's Speech displays the power and authority of God in his life, and by contrast the lack of power and authority in the work of the pseudo-apostles. In this way, he incarnates the Corinthian correspondence's theme of God's power and wisdom empowering weakness and foolishness.

Weakness and foolishness, though different, are related concepts in the Greco-Roman world, as explained in the section above entitled 'The Importance of Paul's Physical Appearance'. In 2 Corinthians 12:9, Paul comes to the pinnacle of the Fool's Speech, a direct statement from the Lord. He writes, '[The Lord] has said to me, «My grace is sufficient for you, for power is perfected in weakness`. Most gladly, therefore, I will rather boast about my weaknesses, that the power of Christ may dwell in me' (2 Corinthians 12:9). Harris has the date of this vision around AD 43 (Harris 1976: 395). Barnett has the date around AD 42 (Barnett 1997: 561). Assuming he received this vision approximately AD 42 ( \pm 1 year), Paul would have had approximately ten years to reflect on Christ's assurance that 'power is perfected in weakness' before writing to the Corinthians that 'God has chosen the foolish things to shame the wise; God has chosen the weak things to shame the strong'. Christ's assertion of sufficiency in weakness directly connects with Paul's assertions in 1 Corinthians 1:27-29. Therefore, the passage in 1 Corinthians (written c. AD 52) likely represents Paul's exegesis of 
Christ's even earlier revelation (c. AD 42) to him through Paul's suffering, but only recently relayed to the Corinthians in 2 Corinthians 12:9 (written c. AD 54). Also, the 'Fool's Speech' demonstrates both Paul's rhetorical skill and his direct application of this revelation to his argument with the pseudo-apostles, that weakness reveals the strength and power of God, certifying Paul's authority in Corinth.

Thus, Paul directly connects his suffering to God's powerful provision, embodying the fool shaming the wise through God's power. He asserts (via a 'theological passive') here that God has sent him his 'thorn' to teach him the need for weakness (Harris 1976: 396). Because Paul's argument highlights the necessity of his suffering, neither Barnett nor Harris attempt to identify the thorn precisely, instead preferring to comment on the repeated efforts by others to do so (Barnett 1997: 568-70; Harris 1976: 396). With regard to Paul's apostleship, Howell writes, 'Thus Paul will 'boast' in his physical infirmities, unlike the supremely confident 'super-apostles' who took pride in oratory and knowledge $(11: 5-6 ; 12: 11)$, because his weakness drove him to fuller reliance on God's strength (12:9b-10; Cf. 11:30)' (Howell 2003: 279). Thus, Paul underlines his need to boast in such things as beatings, flight, and manifold foolishness. These contemptible things provide a chance to see God's strength made perfect-a far more important point to Paul, their apostle. Howell writes, 'Paul's theology of weakness is not a self-deprecating delight in personal pain for its own sake. Rather, harsh realities such as physical ailments, aggressive opponents, malicious verbal attacks, and even physical assaults crush every fiber of self-reliance, so that he becomes an empty vessel through which God's triumphant power can flow (2 Corinthians 12:7-10)' (Howell 2003: 281). Therefore, Paul's apostolic authority gains, rather than diminishes, due to his weakened, beaten state and it is to Paul's enhanced spiritual authority that this article will now turn.

\section{Leadership Implications of the Fool's Speech}

In describing Paul's apostolic mission, Howell writes, 'Paul is the Lord's appointed servant (Acts 26:16) and witness (Acts 9:16) whose sufferings imitate the Servant whom he proclaims' (Howell 2003: 283). He places in a footnote

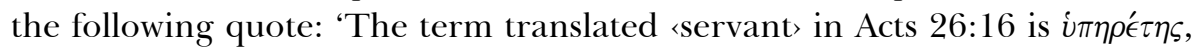
used similarly in 1 Corinthians 4:1 of the Lord's attendant or helper (cf. Acts 13:5). The term originally meant a rower or galley slave and is used perhaps to underscore the humble station that Paul assumes in the Lord's work' (Howell 2003: 283). Howell's comment on this particular term needs some revision due to some further scholarly research performed since the publication of Howell's work. John M. Hitchen refines the definition of

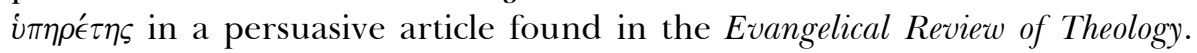


He writes, "Many nineteenth and twentieth century scholars analysed the term etymologically and suggested its component root and prefix mean the hupēretēs was an 〈under-rower〉 as, for instance, in the crew of the trireme-the third, lowest row of rowers propelling ancient warships'. But this explanation is seriously flawed. As Don Carson has shown conclusively, the word never has this 'assistant rower connotation in any clear ancient reference, and there is no evidence of the word being used in that way in New Testament times' (Hitchen 2011: 279). He instead proposes the following definition of the term: '[H]upēretēs [was] particularly applicable to the work of those who researched, wrote, transmitted and cared for the Scriptures. A consistent understanding of the meaning of the term as [employed] in Luke 1:2, 4:20, Acts 13:5 and 26:16 would be, strusted resource custodian`' (Hitchen 2011: 281-82). Therefore, Paul the apostle, served as a custodian of the gospel, which drove him to defend boldly his apostolic authority. However, he did so by highlighting his weakness - a stark contrast to the conventions of leadership and power in the Greco-Roman world. As an apostle of Christ who also founded the Corinthian church, Paul would have been justified in claiming the title of 'leader'. However, Paul did not seek to retain that distinction, preferring to direct praise to God through Christ and to the power of the Holy Spirit. Howell notes, 'Paul's unbending allegiance to the corpus of revealed truth and his bold confrontation of those who depart from it serve as a model for authentic leadership of all ages' (Howell 2003: 257). Paul's rhetorical devastation of the pseudo-apostles incorporated a sweeping acknowledgement of his own weaknesses and his own dishonored status in order to more fully demonstrate his own leadership's dependence on Christ, who required weakness of Paul. Howell writes, '[Paul's] reverential fear of the Lord, to whom he is accountable, is also the driving force behind the passionate defense of his apostolic authority, a defense aimed at striking the consciences of the Corinthian believers with the present danger they face from the [pseudo-apostles]' (Howell 2003: 269). Paul's leadership derives from Christ's commission to him to preach the gospel. Paul's power emerges through the Holy Spirit. In the Fool's Speech, Paul demonstrates his own skillful writing by adapting the contemporary rhetorical conventions to serve the gospel, but his focus on his physical suffering demonstrates his weakness to a church in whose cultural milieu beaten bodies were equated with contemptible character. Paul intensifies his outward foolishness before the Corinthian church before then shaming them through reminders of the enabling power of God in his own life.

Paul demonstrates his leadership through his robust defense of his authority. Had he failed to defend his apostolic authority, the gospel entrusted to him by Christ would have been eviscerated in Corinth. The Corinthians would have been led astray by the pseudo-apostles into following strong, 
beautiful people who were not dependent on Christ for either their strength or authority. Paul recognizes the Corinthian's fascination with rhetoric, and consequently argues according to conventions they understood. However, he infused his rhetoric with a concept foreign to his classical audience: exalting weakness. Nevertheless, 'power through weakness' would not have been incomprehensible to the Corinthians, since Paul gave preview of it in his earlier letter, 1 Corinthians 1:27. Therefore, despite Savage's assertion that Paul did not seek to defend his apostleship, but rather his ministry, Paul clearly seeks both to satirize his opponents, fully defending his apostleship against the pseudo-apostles most notably through sharing what Christian leadership looks like: beaten, broken and empowered by Christ, who himself was beaten and broken. However, Christian leaders can also learn practically from Paul's adaptation of contemporary styles to answer his critics in a way glorifying God. Therefore, the Fool's Speech expands eloquently on the nature of those leaders through whom God shows His power: the fools.

\section{Conclusions}

Paul shamed the pseudo-apostles through the Fool's Speech. In so doing, he incarnates his assertion in 1 Corinthians that God has chosen the foolish to shame the wise. By declaring themselves to be superior to Paul, they opened themselves for his satirical, rhetorically powerful rejoinder. His foolishness in his public speech and his whippability all point to Paul's complete contemptibility according to Greco-Roman standards. There could be no apostle more foolish than Paul to bring the gospel message to the sophisticated Corinthians. However, his masterful skewering of the pseudo-apostles and his impressive adoption of the characteristic conventions of mimic theater prove that he actually is no fool, despite physical appearances and verbal deficits. After this rhetorical display, Paul's apostolic authority appears beyond questioning. Thus, he reminds the Corinthians that, like him, they are to emulate Christ through becoming foolish that God may receive even more glory.

\section{Bibliography}

Avram W (2001) 2 Corinthians 4:1-18. Interpretation 55(1): 70-73.

Barnett P (1997) The Second Epistle to the Corinthians, In: New International Commentary on the New Testament. Grand Rapids, MI: Eerdmans Publishing Company.

Farmer KA (2003) Folly, Fool, Foolish, Simple. In: Gowan DE (ed) The Westminster Theological Wordbook of the Bible. Louisville, KY: Westminster John Knox Press. Pages 140-44. 
Fee G (1997) The First Epistle to the Corinthians. In New International Commentary on the New Testament. Grand Rapids, MI: Eerdmans Publishing Company.

Fordham University: Medieval Sourcebooks (2016) The Acts of Paul and Thecla. In Hone W (ed) The Life of the Holy Martyr Thecla of Iconium, Equal to the Apostles, 1.7 Available at: http://sourcebooks.fordham.edu/Halsall/basis/thecla.asp. [Accessed 5 January 2017].

Glancy JA (2004) Boasting of beatings (2 Corinthians 11:23-25). Journal of Biblical Literature 123(1): 99-135.

Harris MJ (1976) 2 Corinthians. In Gaebelein FE (ed) The Expositor's Bible Commentary with the New International Version. Grand Rapids, MI: Zondervan, 10:301-406.

Hitchen JM (2011) Confirming the Christian scholar and theological educator's identity through New Testament metaphor. Evangelical Review of Theology 35(3): 276-87.

Howell DN (2003) Servants of the Servant: A Biblical Theology of Leadership. Eugene, OR: Wipf and Stock Publishers.

Mare WH (1976) 1 Corinthians. In Gaebelein FE (ed) The Expositor's Bible Commentary with the New International Version. Grand Rapids, MI: Zondervan, 10:175-297.

Roetzel CJ (2009) The language of war (2 Corinthians 10:1-6) and the language of weakness (2 Corinthians 11:21b-13:10). Biblical Interpretation 17(1-2): 77-99.

Savage TB (1995) Power through Weakness. Paul's Understanding of the Christian Ministry in 2 Corinthians. Society for New Testament Studies Monograph Series, 86. Cambridge, England: Cambridge University Press.

Spencer AB (1981) The wise fool (and the foolish wise): a study of irony in Paul. Novum Testamentum 23(4): 349-60.

Stott J (2002) Calling Christian Leaders: Biblical Models of Church, Gospel, and Ministry. Leicester: InterVarsity Press.

Waters LJ (2010) Paradoxes in the Pauline epistles. Bibliotheca Sacra 167(668): 423-41.

Wellborn LL (2002) Moros genestho: Paul's appropriation of the role of the fool in 1 Corinthians 1-4. Biblical Interpretation 10(4): 420-435.

(1999) The runaway Paul. Harvard Theological Review 92(2): 115-163.

Windisch H (1924) Die Narrenrede. Der zweite Korintherbrief. KEK 6, Göttingen: Vandenhoeck \& Ruprecht. 